\title{
The Effects of Earning Management and Financial Performance on the Quality of Islamic Banking Social Responsibility Report
}

\author{
Dina Andyani Pertiwi \\ Deptartement of Accounting \\ Universitas Indonesia \\ Depok, Indonesia \\ dinaandyanip@gmail.com
}

\author{
Evony Silvino Violita* \\ Deptartement of Accounting \\ Universitas Indonesia \\ Depok, Indonesia \\ evony.silvino@gmail.com \\ *Coresponding Author
}

\begin{abstract}
This research aims to show empirical evidence on the association of earning management and financial performance on the Islamic social responsibility of Islamic banks in Indonesia. Firstly, This research examines the indications of the practice of earning management in Islamic banks which is discouraged in Islamic principles. In turn, this research examines the effects of earning management, capital adequacy ratio (CAR), non performing financing (NPF), return on assets (ROA), and financial to deposit ratio (FDR) on the Islamic social responsibility. The study uses discretionary loan loss provision as a proxy of earning management and Islamic Social Reporting index to measure the Islamic Social Responsibility activities. The result shows that there is indications of earnings management practice in Islamic banks in Indonesia. In addition, this study shows that earnings management, CAR, ROA, and FDR do not affect the quality of social responsibility report, while NPF and firm size positively affect the quality of social responsibility report. This research is expected to contribute in Islamic economics and finance literature as well as the regulation recommendation.
\end{abstract}

Keywords: Islamic Bank; Earnings management; Financial performance; Islamic Social Responsibility Report

\section{INTRODUCTION}

In Indonesia, awareness of social responsibility can be seen from the number of firms expressing corporate social responsibility practices in the company's annual report (Fitria and Hartanti, 2010). This is accommodated by the government by issuing regulations on the obligation of disclosure of social and environmental responsibility as regulated in Law no. 40 in 2007 regarding Limited Liability Company which states that annual report must contain some information, one of them is report of implementation of social responsibility and environment (Istiani, 2015). The facts show that many studies found strong correlations between earnings management practices and social responsibility reports (Ibrahim et al., 2015). In addition to earnings management, there are other reasons that influence the practice of social responsibility i.e. financial performance (Ibrahim et al., 2015). Untung (2009) found that the role of the company in realizing the social responsibility is positively correlated with the improvement of the company's financial performance.

Social responsibility is not only in the conventional economy but also thrives in Islamic economy with one of the measurements of social responsibility sharia is Islamic Social Reporting Index (ISR Index). Islamic social responsibility is closely related to the company that runs the business in accordance with the concept of sharia that the company is expected to perform corporate social responsibility in an Islamic way. Islamic banks are an example of business run in the Islamic economic principle. The rapid development of Islamic banks in Indonesia encourages them to disclose social responsibility according to sharia principles (Istiani, 2015). In addition, Islamic banks are also required to comply with Islamic law, where there is a prohibition to perform the manipulation of financial statements in earnings management (Susanti, 2015). However, earnings management practices are difficult to avoid from Islamic banks (Susanti, 2015). Islamic banks in Indonesia also have earnings management practices (Padmantyo, 2010). So it is alleged that earnings management practices affect the disclosure of social responsibility in Islamic banks. In addition to earnings management, financial performance is expected to affect the disclosure of social responsibility of Islamic banks, where the better the financial performance the better the quality of disclosure of social responsibility of Islamic banks.

Previous research conducted by Ibrahim et al. (2015) tested the practice of earnings management and sustainability reporting, between the corporate sectors offering Islamic financial products in Malaysia for a period of three years 20112013 in which incorporates an Islamic perspective. The results of the study found that earnings management had no effect on the quality of sustainability reporting which shows that sustainability reporting is not manipulated to cover earnings management practices. It also found that financial performance positively affected the quality of sustainability report, which means having good financial performance can improve the quality of sustainability report.

This study aims to provide empirical evidence on the effects of earning management and financial performance on 
the quality of social responsibility report of Islamic banks. Explaining the perspective of Islam in conducting business through Islamic values such as accountability and integrity makes this study important. Ibrahim et al. (2015) argued that no previous literature has incorporated earnings management practices and social responsibility reports in an Islamic perspective. Hence, it takes a research to show the combination of earnings management practices and a report of responsibility in the perspective of Islam. In addition, this research is conducted in Indonesia, considering that Indonesia is the largest Muslim population country in the world (Pew Forum on Religion \& Public Life, 2010); so it can be seen the influences of earnings management and financial performance on the quality of the sharia-social responsibility report.

\section{ANALYTICAL FRAMEWORK}

The essence of Stakeholder theory, in maintaining the reputation, banks should not only be seen from the measurement of economic orientation but also incorporates social factors. So the company should do corporate social responsibility to the community that can improve the company's image. Based on the theory, corporate social responsibility has a motive for signaling the quality of management. A disclosure of social responsibility activities is a good signal for stakeholders, in which the company is active in conducting social responsibility activities and the company's value in the public is in a good position. Therefore, good social performance will help the company to obtain a good corporate reputation. In line with agency theory, Islamic bank management has a desire to be considered of having a good performance, one indicator of corporate valuations is profit. In obtaining a good profit, management can practice earnings management, which is contrary to the Islamic Sharia and may provide incorrect information in assessing the company's financial condition.

The practice of earnings management containing elements of uncertainty and deception is contradicted in Islamic sharia, (Ibrahim, 2010). However, the earning management is difficult to avoid (Susanti 2015). This is due to the limited competent human resources in running sharia banks. In addition, the assessment of the performance of Islamic banks is not significantly different from conventional banks. So as to indicate the existence of earnings management practices in Islamic banks. Therefore:

Hypothesis 1: There is earnings management practice in Islamic banks in Indonesia.

Banks need to establish positive image and good corporate profile by revealing the amount of information about social responsibility activities. This makes banks more cautious in engaging in prohibited actions or practices such as earnings management practices. Therefore, the lower the earnings management, the higher the disclosure of social responsibility. Hypothesis 2: Earnings management negatively affects the quality of social responsibility reports of Islamic banks in Indonesia.
Large capital will make banks more flexible in implementing and disclosing the social responsibility. Having large capital gives banks larger opportunity to do social responsibility. Therefore, this study predicts that CAR positively affects the quality of social responsibility report.

Hypothesis 3a: CAR has a positive effect on the quality of social responsibility reports of Islamic banks in Indonesia.

Management's ability to manage problematic financing is demonstrated by the Non Performing Financing (NPF). The low NPF makes banks experience profits, whereas high NPFs make banks suffer losses because they are unable to manage the bank's troubled financing. This disadvantage keeps the bank focused on addressing these issues, thereby tending to override social responsibility activities.

Hypothesis 3b: NPF has a negative effect on the quality of social responsibility reports of Islamic banks in Indonesia.

The higher the ROA, the higher the level of profit achieved by the bank; it shows good performance. High profits will enable the company to provide better information to stakeholders, one of which is the disclosure of social responsibility (Istiani, 2015).

Hypothesis 3c: ROA positively affects the quality of social responsibility reports of Islamic banks in Indonesia.

Istiani (2015) revealed that FDR in accordance with Bank Indonesia safe limits means having a good level of performance. A good level of performance signifies that the bank makes high profit. If banks have high profits, then the funds disbursed for corporate social responsibility are high. This makes banks disclose social responsibilities better.

Hypothesis 3d: FDR positively affects the quality of social responsibility reports of Islamic banks in Indonesia.

\section{RESEARCH METHODS}

The type of data needed to obtain information of all variables in this study is the annual reports of Islamic banks in Indonesia listed on the Financial Services Authority for the period 2011-2014. Total research sample is 40 observations from 10 Islamic banks. Based on the framework, the following is the model of research in this study:

$Q S R_{\text {it }}=\beta_{0}+\beta_{1} D L L P_{\text {it }}+\beta_{2} C A R_{\text {it }}+\beta_{2} N P F_{\text {it }}+\beta_{4} R O A_{\text {it }}+\beta_{5} F D R_{\text {it }}+\beta_{6} S Z E_{\text {it }}+\varepsilon$

Where, QSR = Quality Disclosure of Social Responsibility, = intercept, DLLP = Earnings management, CAR = Capital Adequacy Ratio, NPF = Non-performing Finance, $\mathrm{ROA}=$ Return on Assets, FDR = Financing to Deposit Ratio, Sze = Company Size, $\varepsilon=$ Error

The quality of social responsibility disclosure as measured by the Islamic Social Reporting (ISR) Index was adapted from Othman et al. (2009) with some adjustments. These measurements consist of 42 principal disclosures with six 
themes of disclosure. This study examined the reports of social responsibility in the annual reports of Islamic banks in Indonesia to see each of the items disclosed. To detect earnings management, this study used discretionary loan loss provision from Kanagaretnam (2004) and Taktal et al. (2010), referred to the work of Ali et al (2015). Discretionary loan loss provision was measured using the residual value of these models.

$L L P_{i t}=\alpha_{0}+\beta_{1} N P F_{i t-1}+\beta_{2} C_{\text {CHPNPF }}+\beta_{a} C H F_{i t}+\varepsilon_{i t}$ (1) Where the residual value model is $D L L P_{\text {it }}=L L P-\left[\beta_{1} N P F_{\text {it }-1}+\beta_{2} C H P N P F_{\text {it }}+\beta_{a} C H F_{i t}\right]$ (2). Where, LLP $=$ Loan Loss Provision (total accrual), DLLP = Residual Value (discretionary accruals), NDLLP $=$ Nondiscretionary accrual $=$ Non-performing Balance, beginning of Finance, $=$ Amendment to the Non-performing Finance $=$ Change Total Financing

The financial performance of Islamic banks in this study was measured by financial ratios consisting of capital adequacy ratio (CAR), non performing financing (NPF), return on assets (ROA), and financial to deposit ratio (FDR). The size of the firms was measured by logarithm of natural total asset.

\section{RESULTS AND DISCUSSION}

Based on Pearson correlation test, all independent variables have significant relationships. This study applied a model of random effect model research.

Table 1. Regression Test Results Research Model

\begin{tabular}{|c|c|c|c|}
\hline Variable & Hypothesis & Coefficient & P-value \\
\hline DLLP & $(-)$ & $-0,000206$ & 0.978 \\
\hline CAR & $(+)$ & 0.0627574 & 0.653 \\
\hline NPF & $(-)$ & 1,786077 & $0,029 * *$ \\
\hline ROA & $(+)$ & $-0,2854772$ & 0.777 \\
\hline FDR & $(+)$ & 0.0398959 & .498 \\
\hline SZE & $(+)$ & 0.0802647 & $0,000 * * *$ \\
\hline _cons & & $-1,971245$ & 0.003 \\
\hline R-Square (Overall) & 0.6529 & & \\
\hline Prob> chi2 & 0.0000 & & \\
\hline
\end{tabular}

Source: author results

\section{A. Earning Management}

This study found the practice of earnings management in Islamic banks, where there is residual value of the total loan loss provision which is discretionary loan loss provision. This finding is consistent with research of Karimiyana, et al. (2014), and Ali et al. (2015). This proves that Islamic banks in Indonesia are not yet free from earning management.

The examination of hypotheses two shows earnings management does not affect the quality of social responsibility report ( $p$-value 0.978 ). It proves that Islamic banks conducting ISR to the surrounding community is not due to the earnings management actions. This result is in line with research conducted by Tumewu and Arni (2014) that examined earnings management effects on the disclosure of social responsibility. This result is also consistent with Ibrahim et al. (2015) who found that earnings management has no effect on the quality of sustainability reports.

\section{B. Financial Performance and ISR}

The result shows that CAR does not affect the quality of social responsibility report of Islamic banks in Indonesia which is in line with the studies conducted by Putri (2014) and Kurniawansyah (2013). The results found that NPF positively affects the quality of social responsibility report of Islamic banks. It is consistent with Putri (2014) and Kurniawansyah (2013). ROA is found has no effect on the quality of social responsibility report. The result is in line with Putri (2014), Kurniawansyah (2013), Kamil and Herustya (2012). This is likely because Islamic banks consider the social responsibility important to raise the positive image of the company; So that any profits earned by Islamic banks will not reduce or raise the disclosure of social responsibility performed by Islamic banks (Kamil and Herustya, 2012).

On the other hand, FDR does not affect the quality of social responsibility report of Islamic banks in Indonesia. The result of hypothesis $3 \mathrm{~d}$ shows the level of significance at $\alpha=5 \%$ of 0.498 , which is higher than $5 \%$. The principle of Islam is used in its operational activities, in which Islamic principles prioritize the welfare of society through social responsibility. So the size of the FDR does not necessarily impact to the size of the disclosure of social responsibility in Islamic banks. This indicates that the disclosure of social responsibility in Islamic banks has become a liability both in the high and low FDR conditions. The results of this study are in line with the results of Istiani (2015) and Iswandika (2014) that showed the FDR did not affect the disclosure of social responsibility.

\section{Company Size and ISR}

The study also found that the size of the firms positively affects the quality of social responsibility report. The value of significance at $\alpha=5 \%$ is 0.000 . This is in line with the research conducted by Othman et al. (2009) where the study found that the size of the firms positively affected the disclosure of sharia-social responsibility.. Putri (2014) confirmed that the firm size positively affected the report of sharia-social responsibility. Islamic banks with high total assets have more funding sources to engage in social responsibility activities; so that larger Islamic banks will likely disclose Islamic social responsibility better than smaller Islamic banks. In addition, larger Islamic banks will get more public attention, so they will show their good side by exposing better social responsibility.

\section{CONCLUSION}

Several tests conducted in this study indicated that earnings management practices are run by Islamic banks in Indonesia, where the value of discretionary loan loss provision is a proxy of earnings management. The results of this study found that earnings management does not affect the quality of social responsibility report of Islamic banks in Indonesia. In addition, this study measured financial performance using financial 
ratios consisting of CAR, NPF, ROA, and FDR. In this case, the results of the study found that CAR, ROA, and FDR did not affect the quality of social responsibility report, and NPF positively affected the quality of social responsibility report. The results of this study also found that the size of firms as the control variable positively affected the corporate social responsibility report.

\section{LIMITATIONS AND SUGGESTIONS}

There are limitations in this study. First, there was subjectivity in the assessment and interpretation of the subject disclosure of Islamic social responsibility; so that, further research is expected to find other ways to assess and interpret the main points of social responsibility disclosure by sharia law. Second, the limited research data made the values of financial ratios resulting minus are not removed within that required additional research data samples and the number of [ periods.. Third, this study was conducted in one country, Indonesia, so that further research can expand its scope in several other countries to see the differences in each country, and the overall look of Islamic banks in the world. Fourth, this [11 study measured the financial performance of the financial ratios; and the financial ratios used are CAR, NPF, ROA, and FDR. Thus, further research may add other relevant financial ratios to illustrate better financial performance. Fifth, earnings management proxies were used in this study only to detect whether or not there is an earnings management in Islamic banks but cannot confirm the motivation of Islamic banks in managing earnings. Therefore, a better proxy of earnings management is necessary to find out the motivations of Islamic banks in managing earnings.

\section{REFERENCES}

[1] Ali, F. Saiti, B. Hamzah, S. Ariff, M. (2015). The Impact of [16] Efficiency on Discretionary Loans / Finance Loss Provision: A Comparative Study of Islamic and Conventional Banks. Borsa Istanbul Review 272-282.

[2] Ibrahim, A. (2010). Income Smoothing and Its Implications Towards Corporates' Income Reporting in the Context of [17] Islamic Economic Ethics. Islamic Media Journal, vol XII no. 24.

[3] Ibrahim MS, Yusoff, H., Darus, F., Mohammed, R. (2015). [18] Analysis of Earnings Management Practices and Sustainability Reporting for Corporations that offer Islamic Products and Services. Procedia Journal of Economics and Finance, 28 (2015) 176-182.

[4] Istiani, F. (2015). Effect of Bank Size, Profitability, Liquidity, and Leverage Against Islamic Social Reporting [19] Disclosure. Essay. Faculty of Sharia and Law UIN Syarif Hidayatullah.

[5] Iswandika., Ryandi. (2014). Effect of Financial Performance, Corporate Governance and Audit Quality Of Disclosure of Corporate Social Responsibility. Journal of Accounting from Trisakti University, volume 1 no. 2, h.1-[21] 18.

[6] Kamil, A., Herusetya, A. (2012). The Effect of Corporate Characteristics on The Extent of Corporate Social
Responsibility Disclosure Activities. Media Accounting Research, vol. 2, no. 1.

[7] Karimiyana, A.A, Norfian, M. \& Nasserinia, A. (2014). Signaling view of Loan Loss Provision in Islamic Banks of Malaysia. International Journal of Management Sciences and Business Research, 3, 2226-8235.

[8] Kurniawansyah, D. (2013). Analysis of Financial Relations and Corporate Social Responsibility Performance: Empirical Study of Banking Listed in Indonesia Stock Exchange. Essay. Faculty of Economics and Business, University of Diponegoro (Unpublished).

[9] Oktafia, Y. (2013). Effect of Earnings Management Disclosure Of Corporate Social Responsibility to Corporate Governace As Variable Moderation. Scientific Journal of Accounting and Humanika Jinah, vol. 2 no. 2, ISSN 20893310 .

Othman, R., Thani, AM, \& Ghani, EK (2009). Reporting Social Determinants of Islamic Sharia-Approved Among Top Companies in Bursa Malaysia. Research Journal of International Studies.

Padmantyo, S. (2010). Analysis of Earnings management in the Financial Statements of Islamic Banking. Journal of Management and Business, vol. 14, no. 2, pp 53-65.

12] Pew Forum on Religion \& Public Life. 2010. http://www.pewforum.org/

13] Putri, S.M.K. (2014). Company Characteristics Influence Against Islamic Social Disclosure Reporting on Islamic Banking. Essay. Faculty of Economics, University of March.

14] Republic of Indonesia Government, Act No. 28 of 2001 concerning Islamic Banking.

[15] Republic of Indonesia Government, Act No. 40 Year 2007 regarding Limited Liability Company.

Fitria, S., Hartanti, D. (2010). Islamic and Social Responsibility: Comparative Study of Disclosure Based on Global Reporting Index and Islamic Social Reporting Index. National Symposium Accounting XIII Purwokerto, h.2.

Susanti, D. (2015). Motivation Earnings management at Bank Islam in Indonesia and Malaysia. Essay. Faculty of Economics and Business, University of Indonesia.

Tumewu, S., Arni, F. (2014). Effect of Earnings Management Of Disclosure of Corporate Social Responsibility and Corporate Financial Performance in Banking Industry Listed on the Stock Exchange Period 2010-2012. Surabaya University Student Science Journal, vol.3, no. 2 .

Untung, H.B. (2009). Corporate Social Responsibility. Jakarta: Sinar Grafika.

[20] Violita, et al. 2014. Role of Mediation Institutional against Relationships between Cultural Values and Disclosures Islamic Values. Journal of Accounting and Finance IndonesiaVolume 11 Number 2.v

http://www.bi.go.id/

http://ojk.go.id 